\title{
Yield and Yield-Related Parameters of Tomato (Lycopersicon esculentum Mill.) Treated with Paclobutrazol at Different Stages in North West Ethiopia
}

\author{
Walelegn Endegena \\ Ethiopian Biodiversity Institute, crop and horticulture biodiversity directorate, Addis Abeba Ethiopia, \\ P.O. Box; 26307 \\ addistadessse@gmail.com
}

Keywords: Paclobutrazol (PBZ), effect, rate and time of application, interaction, Fruit yield, economic earliness

\begin{abstract}
The effects of Paclobutrazol (PBZ) on fruit yield of tomato (Lycopersicon esculentum Mill.) were investigated by spraying it on tomato seedlings grown in an open field. The treatments were $5 \times 2$ factorial combinations including five rates of PBZ (control, $1 \mathrm{~kg} \mathrm{ha}^{-1}, 2 \mathrm{~kg} \mathrm{ha}^{-1}, 3 \mathrm{~kg} \mathrm{ha}^{-1}$ and $4 \mathrm{~kg} \mathrm{ha}^{-1}$ ) and two times of application (at 2 to 4 and 6 to 8 true leaf growth stages of tomato seedlings), arranged in a Randomized Complete Block Design, each treatment replicated three times. The objective of the study was to characterize the effect of rate and time of application of PBZ on the yield and yield related parameters of tomato. Time and rate of application of PBZ significantly increased harvest index, yield concentration and index of economic earliness, and decreased fruit set percentage, pericarp thickness, fruit diameter and percentage of class one fruit. Irrespective of the time of application, an increase in the rate of PBZ compared to the control significantly increased days to fruit maturity. Time and rate of application of PBZ were significantly interacted to increase; unmarketable fruit yield but decrease means fruit weight. Compared to the control, the interaction effects also produced two significant trends of variations on fruit yield per plant, fruit dry weight per plant, marketable fruit yield and total fruit yield. Significant reduction in yields was observed for diluted concentrations like 1 and $2 \mathrm{~kg} / \mathrm{ha}$ a.i. of PBZ in the second time of application and $1 \mathrm{~kg} / \mathrm{ha}$ a.i. of PBZ in the first time of application, whereas all other treatments produced significantly higher yields than the controls. On the contrary, time and rate of application of PBZ were found to be effective in improving economic earliness of tomato. As a whole, time and rate of application of PBZ resulted in two significant trends of variations (increasing and decreasing) on fruit yields of tomato. Hence, it could be possible to propose that more assimilate reallocation to the fruits are significant advantage of PBZ treatments contributing to the improvement of seedling quality at planting for increased seedling survival rate, better stress protection, early and more fruit production.
\end{abstract}

\section{Introduction}

The cultivated tomato (Lycopersicon esculentum L Mill) belonging to the family Solanaceae is an important vegetable crop in the world. Its fruit is very popular among solanaceous vegetables used as a source of minerals and vitamins in the diet of all continents [1]. It ranks first in production among the most important vegetable crops in many countries. It is also among the most important vegetable crops in Ethiopia [8]. In Ethiopia, tomato is produced mainly as a source of income and food both under rainfed and irrigated conditions [7].

Tomato production in Ethiopia was characterized by seasonality and low yield. The use of varieties, which are late maturing and low yielder, therefore, was one of the chief production constraints of Ethiopian tomato production [7].

In order to alleviate the main production constraint of this crop, Ethiopian Agricultural Research Organization (EARO) accomplished remarkable results through systematic research in various centers. The yields of these recommended varieties are not utilized to their full production potential because of exposure of the crop to various environmental stresses. Marglobe (used in this experiment) is the most common variety grown in Ethiopia and but it is one of such varieties which are underutilized. 
The price of tomato in the market is also attractive when produced during the slack period of production. However, low productivity and poor quality fruits are common problems, because of susceptibility of the plant to environmental stresses, diseases and insect pests. PBZ treatment affects the quality of the seedlings, early fruit yield, total fruit yield, quality of fruit and index of economic earliness of several fruits and vegetables through regulation of sink priority [17].

Paclobutrazol is known to influence the earliness of production and quantity of tomato fruit produced to solve the problem of environmental stresses, seasonality and productivity.

In Ethiopia, no experiment has been carried out and no information is available regarding the effects of PBZ on yield and economic earliness in tomato production to be used as possible alternatives to ensure better components of early maturity, better yield and fruit quality. Hence, the study was initiated with the objectives of investigating the effects of PBZ treatment on yield, and economic earliness of tomato.

\section{Materials and Methods}

\subsection{Description of the Experimental Site}

The experiment was conducted in North-western Ethiopia at a farmer's field located $310 \mathrm{~km}$ away from Addis Ababa at 10'23'50' Latitude, 38 12'47' 'Longitude and an altitude of 2159 m.a.s.1. The mean annual rainfall of $1677 \mathrm{~mm}$ and the effective rainy season is from May to October with a peak in July receiving a monthly mean of $385 \mathrm{~mm}$. Its mean maximum temperature ranges from $21.1^{\circ} \mathrm{C}$ in August to $28{ }^{\circ} \mathrm{C}$ in April and mean minimum temperatures ranging from $5.2{ }^{\circ} \mathrm{C}$ in January to $11.5^{\circ} \mathrm{C}$ in September. The site has a slope of $3-4 \%$ and the soil of the site has a texture of siltyclay-loam with a $\mathrm{pH}$ of 5.62 .

\subsection{Nursery Management}

The nursery site was prepared in the back-yard of a farmer. Seeds were sown on ten seed beds with each bed having a bed length of $1.44 \mathrm{~m}$ and width of $1 \mathrm{~m}\left(1.44 \mathrm{~m}^{2}\right)$ with $1 \mathrm{~m}$ spacing between the beds. Seedlings were thinned out at a spacing of $5 \mathrm{~cm}$ between plants and $12 \mathrm{~cm}$ between rows two days before the first treatment application to maintain a total of 100 seedlings per bed ( 5 rows and 20 plants per row). Seedlings were irrigated every day and hand weeding was done to control weeds till they become ready for transplanting.

\subsection{Experimental Treatments}

Seedlings were treated with PBZ at rates of $0,1,2,3$, and $4 \mathrm{~kg}$ active ingredient (a.i.) PBZ $\mathrm{ha}^{-1}$ as a foliar application using the Cultar formulation $(250 \mathrm{~g}$ a.i. PBZ per litre, Zeneca Agrochemicals SA (Pty Ltd, South Africa)). The treatments were applied at 2 to 4 or 6 to 8 true leaf growth stage. To prepare aqueous solutions, a given PBZ concentration was diluted in distilled water and applied to each seedling as a fine foliar spray using an atomizer until runoff was reached. The control plants were treated with distilled water at equivalent volumes.

\subsection{Experimental Design and Field Management}

The experimental plots were set up using a 2 x 5 factorial combination in Randomized Complete Block Design with three replications. The treatments include 2 times and 5 rates of PBZ applications. Each plot was $5.4 \mathrm{~m}$ longer and $1.5 \mathrm{~m}$ wider with a gross area of $\left(8.1 \mathrm{~m}^{2}\right)$ and a net harvest area of $3.6 \mathrm{~m} \times 0.9 \mathrm{~m}\left(3.24 \mathrm{~m}^{2}\right)$. Seedlings were planted at $90 \mathrm{~cm}$ inter-row and $30 \mathrm{~cm}$ intra-row spacing. There were six planting rows and five plants per row with a spacing of $1 \mathrm{~m}$ between plots and $1.5 \mathrm{~m}$ between blocks, each plot has 30 tomato plants which is equivalent to 37,037 plants per hectare.

Seedlings were hardened for 10 days by reducing the frequency of watering before transplanting. Healthy, vigorous, and stocky seedlings were selected and transplanted 49 days after emergence. Transplanting was done late in the afternoon. The plots were furrow irrigated twice per week. Staking was done at fruit set. Other agronomic practices (weeding, hoeing and others) were done as deemed essential and no pests or diseases of significant importance were observed. 


\subsection{Data Collection}

\section{Yield and yield component parameters}

1. Number of primary branches per plant: the number of primary branches arising from the main stem.

2. Fruit set (\%): Fruit set percentage was recorded when the first fruit was $2 \mathrm{~mm}$ in diameter.

3. Number of fruit per truss and per plant: The total number of fruits in all the trusses divided by the number of trusses to get number of fruits in a truss and number of fruits per plant represents the total numbers of fruits of successive harvests.

4. Fruit diameter (cm): Five fruits of different size (very large, large, medium, small and very small) were collected from each selected plant and the diameter of each fruit was measured by using the caliper. The mean diameter of fruit was obtained by adding the diameter of all the selected fruits and then dividing the sum by the number of selected fruits. The transverse fruit dimensions were recorded at full maturity. Tomato fruit $\geq 6 \mathrm{~cm}$ in diameter was considered as class one fruit.

5. Pericarp thickness ( $\mathbf{m m})$ : Five fruits of different size (very large, large, medium, small and very small) were collected from each selected plant. Each fruit was cut into two halves through the equator and the thickness of the pericarp was measured by a caliper. The mean thickness of the pericarp was obtained by adding the pericarp thickness of all the selected fruits and then dividing the sum by the number of selected fruits.

6. Average fruit weight (g): obtained by dividing total fruit yield per plant by the number of fruit.

7. Early fruit yield (tons/ha): tomato fruit harvested in the first five harvests out of the total harvest were considered as early yield. The average early yield in tons per hectare was found by converting tomato fruit yield harvested in the first five successive harvests from the net harvest area $\left(3.24 \mathrm{~m}^{2}\right)$ into hectare.

8. Total fruit yield per plant (g): At each harvest, fruits which were free of damage and with a size greater than $30 \mathrm{~g}$ were considered as marketable. On the contrary, fruits which were damaged by insect, diseases, and sunburn, etc. and a size less than or equals to $30 \mathrm{~g}$ were considered as unmarketable. Total fruit yield per plant is the sum of marketable and unmarketable fruit yield.

9. Marketable, unmarketable and total fruit yield per hectare (ton): This was obtained by converting the unmarketable and marketable fruit yield of the successive harvests obtained from the net harvest area of $3.6 \mathrm{~m} \mathrm{x} 0.9 \mathrm{~m}\left(3.24 \mathrm{~m}^{2}\right)$ into hectare. Total fruit yield is the summation of unmarketable and marketable fruit yield.

10. Dry mass of individual fruit (g): Three fruits of different size were selected from each plot and all the selected fruits were chopped into pieces for hastening the time of drying and they were dried in an oven at a temperature of $80{ }^{\circ} \mathrm{C}$ until constant mass was obtained. The dry mass of the fruits was added and the sum was divided by the number of fruits to obtain the mean dry mass of individual fruit.

On the basis of the above parameters, the following yield and yield related parameters were computed.

1. Harvest index: it is the ratio of economic yield to total biomass or biological yield.

2. Index of economic earliness (\%): indicates percentage of early fruit yield (fruit harvested in the first five harvests) from total fruit yield. Early fruit yield is already recorded and it is given by the following formulae or equation:

$$
\mathrm{IEE} \%=\frac{\text { Early fruit yield }}{\text { Total fruit yield }} \mathbf{x} 100
$$

where early fruit yield is the yield from the first five harvests and IEE= Index of economic earliness

3. Yield concentration $(\%)$ : indicates the percentage of marketable fruit obtained from the first harvest in relation to total fruit yield. 
Yield Concentration $=\frac{\text { first marketable fruit yield }}{\text { Total fruit yield }} \times 100 ;$ for a single harvest.

\subsection{Data Analysis}

The data collected were subjected to analysis of variance (ANOVA) by using SAS for Window v8 software and comparison of means was made using least significance difference (LSD) at 5\% and $1 \%$ probability level.

\section{Result and Discussion}

\subsection{Yield and Yield related parameters}

\subsubsection{Number of primary branch per plant}

The number of primary branch per plant of tomato was significantly affected by the interaction effect of rate and time of PBZ application (Table 1). More branching in response to PBZ treatment may be due to the establishment of vigorous and good quality seedling in the early growth stage. The results of this experiment are in harmony with the finding of [13] who reported that triazoles such as PBZ modify plant structures by enhancing number and angle of insertion of primary branches on the main axis of Indian cultivar of rape. Contrary to this, Merlo et al. [9] reported that the reduced number of branches per plant on soybean.

\subsubsection{Number of truss per plant, number of flower per truss and plant}

The number of truss per plant, flower per truss and per plant were significantly affected by the interaction effect of rate and time of application of PBZ (Table 1). In general, the number of truss per plant, number of flower per truss and plant progressively increased with an increase in rate of PBZ for both times of application. Enhancing the number of truss and number of flower in response to PBZ treatment may be related to its effect of GA and cytokinin biosynthesis. Zhu et al. [18] observed an increase in endogenous cytokinin (Zeatin) level in xylem sap of a young apple tree in response to PBZ treatment. In agreement with the current finding, PBZ treatment increased the number of flowers per plant in tomato [3]. On the contrary, Park and Lee [11] demonstrated a reduction in flower number in response to PBZ treatment in Hambule pepper. The number of flowers produced per plant was positively and strongly associated with the number of primary branches indicating that PRZ treatment increased the number of flowers by enhancing more branching in tomato.

Table 1. Number of primary branch per plant, number of truss per plant, number of flower per truss, and number of flower per plant as influenced by the interaction effect of time and rate of application of PBZ

\begin{tabular}{lcccccc}
\hline $\begin{array}{l}\text { Time of } \\
\text { application }\end{array}$ & $\begin{array}{c}\text { Rate of } \\
\text { application }\end{array}$ & $\begin{array}{c}\text { No of primary } \\
\text { branches per } \\
\text { plant }\end{array}$ & $\begin{array}{c}\text { Fruit set } \\
\text { percentage }\end{array}$ & $\begin{array}{c}\text { Number of } \\
\text { trusses per } \\
\text { plant }\end{array}$ & $\begin{array}{c}\text { Number of } \\
\text { flowers } \\
\text { per truss }\end{array}$ & $\begin{array}{c}\text { Number } \\
\text { of flowers } \\
\text { per plant }\end{array}$ \\
\hline $\begin{array}{l}2-4 \text { true leaf } \\
\text { stage }\end{array}$ & 0 & $3.33^{\mathrm{f}}$ & $85.46^{\mathrm{b}}$ & $5.48^{\mathrm{c}}$ & $3.67^{\mathrm{f}}$ & $20.82^{\mathrm{f}}$ \\
& $1 \mathrm{~kg}$ & $4.25^{\mathrm{d}}$ & $88.35^{\mathrm{a}}$ & $5.66^{\mathrm{abc}}$ & $4.66^{\mathrm{e}}$ & $26.41^{\mathrm{e}}$ \\
& $2 \mathrm{~kg}$ & $4.85^{\mathrm{c}}$ & $* *$ & $5.70^{\mathrm{a}}$ & $5.94^{\mathrm{c}}$ & $33.89^{\mathrm{b}}$ \\
& $3 \mathrm{~kg}$ & $5.44^{\mathrm{b}}$ & 0.63 & $5.74^{\mathrm{a}}$ & $6.46^{\mathrm{b}}$ & $37.09^{\mathrm{a}}$ \\
& $4 \mathrm{~kg}$ & $5.91^{\mathrm{a}}$ & & $5.79^{\mathrm{a}}$ & $6.62^{\mathrm{a}}$ & $38.22^{\mathrm{a}}$ \\
& $3.34^{\mathrm{f}}$ & $97.48^{\mathrm{a}}$ & $5.49^{\mathrm{c}}$ & $3.65^{\mathrm{f}}$ & $20.75^{\mathrm{f}}$ \\
& & & & & &
\end{tabular}




\begin{tabular}{|c|c|c|c|c|c|c|}
\hline \multirow{4}{*}{$\begin{array}{l}6-8 \text { true leaf } \\
\text { stage }\end{array}$} & $1 \mathrm{~kg}$ & $3.85^{\mathrm{e}}$ & $87.13^{b}$ & $5.50^{c}$ & $4.54^{\mathrm{e}}$ & $24.91^{\mathrm{e}}$ \\
\hline & $2 \mathrm{~kg}$ & $4.04^{\mathrm{de}}$ & $85.10^{\mathrm{b}}$ & $5.51^{b c}$ & $4.70^{\mathrm{e}}$ & $25.90^{\mathrm{e}}$ \\
\hline & $3 \mathrm{~kg}$ & $4.28^{\mathrm{d}}$ & $84.29^{b}$ & $5.69^{a}$ & $5.25^{\mathrm{d}}$ & $29.90^{\mathrm{d}}$ \\
\hline & $4 \mathrm{~kg}$ & $4.73^{c}$ & $80.50^{c}$ & $5.71^{\mathrm{a}}$ & $5.61^{\mathrm{c}}$ & $32.00^{c}$ \\
\hline \multicolumn{2}{|c|}{ Significance level } & $* *$ & $* *$ & $* *$ & $* *$ & $* *$ \\
\hline \multicolumn{2}{|l|}{$\operatorname{SEM}( \pm)$} & 0.11 & 1.00 & 0.19 & 0.13 & 0.55 \\
\hline \multicolumn{2}{|l|}{$\mathrm{CV}(\%)$} & 4.40 & 2.81 & 1.82 & 4.36 & 3.26 \\
\hline
\end{tabular}

**: significant at $1 \%$ probability level. Means of the same main effect within a column followed by the same letter are not significantly different at $1 \%$ probability level.

\subsubsection{Fruit Set percentage}

Fruit set percentage was significantly affected by both time and rate of PBZ application as presented in Table 1. There was a decreasing pattern in fruit set percentage in response to increasing the rate of PBZ application. In this regard, Atherton and Rudich [2] pointed out that an increase in the number of flowers initiated will increase potential for competition and for subsequent reduction in fruit size. In agreement with the current finding, Frost and Kretchman [4] reported reduced fruit set percentage on the terminal region of PBZ treated tomato. Various sink organs have different abilities to attract assimilate (i.e., sink strength), and thus the priority of an organ in receiving assimilates is the result of competition among sink organs (i.e., sink competition) [6]. This priority is best assessed by the proportional assimilate distribution when assimilate supply is limited, as assimilate will first be taken up by the strong sink. The weaker sinks may or may not receive assimilate depending on its availability.

\subsubsection{Number of fruit per truss, number of fruit per plant and fruit yield per plant}

The number of fruit per truss and per plant and fruit yield per plant were significantly affected by the interaction effect of rate and time of PBZ application (Table 2). In general, for both stage of application, the number of fruit per truss and per plant increased with an increase in the rate of PBZ applied. The increase in a number of yield per plant, fruit per truss and plant in response to PBZ treatment could be attributed to its effect on assimilate partitioning in favour of reproductive organs and increase in root to shoot ratio. Bevora and Zlatev [3], in their investigation, it was reported that foliar application of PBZ significantly reduced fruit yield of tomato while drench application significantly increased fruit yield of tomato indicating that method of application influences the effect of PBZ by increasing root to shoot ratio compared to the foliar application. Fruit yield per plant was positively associated with fruit number per truss and fruit number per plant but negatively correlated with mean fruit weight indicating that PBZ treatment improved fruit yield by increasing fruit number although it decreased individual fruit size. 
Table 2. Number of fruit per truss and per plant, mean fruit weight, fruit yield per plant and fruit dry weight per plant, as affected by the interaction effect of time and rate of PBZ Application

\begin{tabular}{|c|c|c|c|c|c|c|}
\hline $\begin{array}{l}\text { Time of } \\
\text { application }\end{array}$ & $\begin{array}{l}\text { Rate of } \\
\text { application }\end{array}$ & $\begin{array}{l}\text { Number } \\
\text { of fruits } \\
\text { per truss }\end{array}$ & $\begin{array}{l}\text { Number of } \\
\text { fruits per } \\
\text { plant }\end{array}$ & $\begin{array}{l}\text { Mean fruit } \\
\text { weight }(\mathrm{g})\end{array}$ & $\begin{array}{ll}\text { Fruit } & \text { Yield } \\
\text { per } & \text { plant } \\
(\mathrm{g}) & \end{array}$ & $\begin{array}{l}\text { Fruit dry } \\
\text { weight per } \\
\text { plant (g) }\end{array}$ \\
\hline \multirow{5}{*}{$\begin{array}{l}\text { 2-4 true leaf } \\
\text { stage }\end{array}$} & 0 & $3.58^{\mathrm{f}}$ & $16.96^{\mathrm{e}}$ & $59.62^{\mathrm{a}}$ & $1252.76^{\mathrm{d}}$ & $126.58^{\mathrm{e}}$ \\
\hline & 1 & $4.03^{\mathrm{e}}$ & $22.84^{\mathrm{d}}$ & $51.58^{\mathrm{bc}}$ & $1168.40^{\mathrm{e}}$ & $130.34^{\mathrm{d}}$ \\
\hline & 2 & $4.97^{\mathrm{bc}}$ & $28.36^{\mathrm{b}}$ & $49.89^{\text {cd }}$ & $1413.06^{\mathrm{b}}$ & $144.91^{\mathrm{b}}$ \\
\hline & 3 & $5.33^{\mathrm{a}}$ & $30.58^{\mathrm{a}}$ & $49.82^{\mathrm{cd}}$ & $1523.80^{\mathrm{a}}$ & $153.88^{\mathrm{a}}$ \\
\hline & 4 & $5.09^{\mathrm{ab}}$ & $29.39^{\mathrm{ab}}$ & $48.79^{d}$ & $1434.12^{b}$ & $147.74^{\mathrm{b}}$ \\
\hline \multirow{5}{*}{$\begin{array}{l}6-8 \text { true leaf } \\
\text { stage }\end{array}$} & 0 & $3.56^{\mathrm{f}}$ & $16.80^{\mathrm{e}}$ & $60.24^{\mathrm{a}}$ & $1259.46^{\mathrm{d}}$ & $126.56^{\mathrm{e}}$ \\
\hline & 1 & $3.98^{\mathrm{e}}$ & $21.84^{\mathrm{d}}$ & $52.12^{\mathrm{b}}$ & $1136.90^{\mathrm{e}}$ & $127.00^{\mathrm{d}}$ \\
\hline & 2 & $4.07^{\mathrm{e}}$ & $22.42^{\mathrm{d}}$ & $51.83^{\mathrm{bc}}$ & $1161.39^{\mathrm{e}}$ & $129.94^{\mathrm{dc}}$ \\
\hline & 3 & $4.53^{\mathrm{d}}$ & $25.77^{\mathrm{c}}$ & $50.50^{\mathrm{bcd}}$ & $1321.95^{c}$ & $132.47^{\mathrm{c}}$ \\
\hline & 4 & $4.71^{\mathrm{cd}}$ & $26.88 \mathrm{c}$ & $50.16^{\mathrm{bcd}}$ & $1403.06^{\mathrm{b}}$ & $137.60^{c}$ \\
\hline \multicolumn{2}{|c|}{ Significance level } & $* *$ & $* *$ & $* *$ & $* *$ & $* *$ \\
\hline \multicolumn{2}{|l|}{$\operatorname{SEM}( \pm)$} & 0.10 & 0.47 & 0.72 & 18.30 & 1.89 \\
\hline \multicolumn{2}{|l|}{$\mathrm{CV}(\%)$} & 4.07 & 3.28 & 2.38 & 2.42 & 2.47 \\
\hline
\end{tabular}

**: significant at $1 \%$ probability level. Means of the same main effect within a column followed by the same letter are not significantly different at $1 \%$ probability level

\subsubsection{Mean fruit weight and fruit dry weight per plant}

Stage and rate of PBZ application interacted significantly to influence mean tomato fruit weight and fruit dry weight per plant (Table 2).

\subsubsection{Marketable, unmarketable and total fruit yield}

The interaction effect of time and rate of PBZ application significantly affected marketable, unmarketable and total fruit yield of tomato (Table 3). The results show that unmarketable fruit yields are significantly increased with an increase in the rate in both application stages that could be due to the reduction in fruit size in response to the treatment. In agreement with this, different researchers observed that PBZ treatment reduced fruit sizes and it was the main reason for an increase in an unmarketable fruit yield [10, 15]. Significant total tomato fruit yield increment in response to the PBZ application have been reported by Orzolek [10], Souza-Machado et al. [15] and Bevora and Zlatev [3]. Similarly, PBZ considerably increased fruit yield in tomato that may be through improving and enhancing transplant quality, the number of branches, early flowering and fruiting, retaining photosynthetically active leaves longer in response to the treatment and increased duration of fruit production.

Table 3. Unmarketable, marketable and total fruit yield, as influenced by the interaction effect of time and rate of application of PBZ 


\begin{tabular}{lcccc}
\hline application & Application (kg) & Unmarketable & Marketable & Total \\
\hline 2-4 true leaf growth stage & 0 & $2.40^{\mathrm{g}}$ & $44.00^{\mathrm{d}}$ & $46.40^{\mathrm{d}}$ \\
& 1 & $2.69^{\mathrm{f}}$ & $40.58^{\mathrm{e}}$ & $43.27 \mathrm{e}$ \\
& 2 & $3.17^{\mathrm{bc}}$ & $49.17^{\mathrm{b}}$ & $52.34^{\mathrm{b}}$ \\
& 3 & $3.29^{\mathrm{b}}$ & $53.15^{\mathrm{a}}$ & $56.44^{\mathrm{a}}$ \\
6-8 true leaf growth stage & 4 & $3.48^{\mathrm{a}}$ & $49.64^{\mathrm{b}}$ & $53.12^{\mathrm{b}}$ \\
& 0 & $2.36 \mathrm{~g}$ & $44.29^{\mathrm{dc}}$ & $46.65^{\mathrm{d}}$ \\
& 1 & $2.60^{\mathrm{f}}$ & $36.50^{\mathrm{e}}$ & $42.11^{\mathrm{e}}$ \\
& 2 & $2.76^{\mathrm{ef}}$ & $40.25^{\mathrm{e}}$ & $43.01^{\mathrm{e}}$ \\
Significance level & 3 & $2.92^{\mathrm{de}}$ & $46.04^{\mathrm{c}}$ & $48.96^{\mathrm{c}}$ \\
SEM $( \pm)$ & 4 & $3.07^{\mathrm{dc}}$ & $48.90^{\mathrm{b}}$ & $51.97^{\mathrm{b}}$ \\
CV $(\%)$ & & $* *$ & $* *$ & $* *$ \\
& & 0.05 & 0.66 & 0.68 \\
\hline
\end{tabular}

**: significant at $1 \%$ probability level. Means of the same main effect within a column followed by the same letter are not significantly different at $1 \%$ probability level

Mean fruit weight positively and strongly associated with fruit diameter and pericarp thickness indicating that PBZ treatment reduced average fruit weight by decreasing both fruit diameter and pericarp thickness. The highest fruit dry weight per plant was obtained from spraying of $3 \mathrm{~kg}$ a.i. PBZ $\mathrm{ha}^{-1}$ at 2-4 true leaf stage while the least was from the control. The increase in fruit dry matter in response to PBZ treatment could be attributed to its effect on assimilates partitioning in favour of reproductive organs and increase in root to shoot ratio. Paclobutrazol treatments remarkably affected the overall pattern of carbon fixation and assimilate partitioning to different potato organs. In this study, fruits were found to be the dominant sinks that attracted the highest proportion of DM relative to the leaves and stems. This may probably be attributed to the strong assimilate attraction power of developing fruit over other parts. There is evidence that the developing seed and fruit are strong sinks which have priority over vegetative organs in the partitioning of assimilates $[19,20]$. This dominance is believed to be mediated by phytohormones because developing seeds and fruit are rich sources of several plant hormones, including cytokinins, IAA, ABA and GA3 [5].

\subsubsection{Total dry biomass per plant and harvest index}

The rate of PBZ application significantly influenced total biomass production per plant while the time of application did not (Table 4). Both the time and rate of PBZ application significantly affected the harvest index of tomato (Table 4). Application of $1 \mathrm{~kg}$ a.i. PBZ ha ${ }^{-1}$ decreased total biomass yield per plant. Regardless of the rate application, PBZ at 6-8 true leaf sage encouraged the production of higher total biomass per plant than treating during 2-4 true leaf stage. PBZ treatment inhibits GA biosynthesis and subsequently modulates hormonal balance and thereby probably influences the pattern of assimilating production and allocation. Reduction in total biomass yield was accounted to the reduction in leaf number and size. Bevora and Zlatev [3] observed slightly lower dry biomass in PBZ treated tomato plants that the control. A significant total dry weight reduction in potato in response to PBZ treatment reported by Tekalign and Hammes [16]. Harvest index progressively increased with increasing the rate of PBZ application. 
Remarkable improvement in harvest index due to PBZ treatment was attributed to a significant reduction in total biomass while increasing assimilates partitioning to the fruit. After PBZ treatment, assimilate was redistributed and used more efficiently indicating that vegetative growth reduction was affected by a change in relative attraction force of the plant organs, directing most assimilates to reproductive growth [3]. PBZ treatment increase partitioning of assimilates to economically important plant parts such as bulbs $[14,16]$ thereby improved harvest index.

\subsubsection{Yield concentration and index of economic earliness}

Both stage and rate of PBZ application remarkably influenced yield concentration and index of economic earliness (Table 4). Regardless of the concentration, PBZ treatment at 2-4 true leaf stage increased yield concentration by $10.24 \%$ \& index of economic earliness by $8.20 \%$ as compared to applying at 6-8 true leaf stage. Application of 3 or $4 \mathrm{~kg}$ a.i. $\mathrm{PBZ} \mathrm{ha}{ }^{-1}$ increased yield concentration and index of economic earliness respectively as compared to the respective checks. The increase in yield concentration and fruit yield from the first five harvests (index of economic earliness) was accounted to early flower formation and partitioning of more assimilates to the fruit. In favour of the current finding, Bevora and Zlatev [3] reported a significant increase in the index of economic earliness.

Table 4. Total dry biomass per plant, harvest index, yield concentration and index of economic earliness as influenced by time and rate of PBZ application

\begin{tabular}{|c|c|c|c|c|}
\hline Treatment & $\begin{array}{l}\text { Total dry biomass } \\
\text { per plant }(\mathrm{g})\end{array}$ & $\begin{array}{c}\text { Harvest } \\
\text { index }(\%)\end{array}$ & $\begin{array}{c}\text { Yield } \\
\text { concentration }\end{array}$ & $\begin{array}{l}\text { Index of } \\
\text { economic } \\
\text { earliness }\end{array}$ \\
\hline \multicolumn{5}{|l|}{ Time } \\
\hline 2-4 true leaf growth stage & 256.59 & $55.76^{\mathrm{a}}$ & $77.14^{\mathrm{a}}$ & $69.24^{\mathrm{a}}$ \\
\hline $6-8$ true leaf growth stage & 263.96 & $49.68^{\mathrm{b}}$ & $69.97^{\mathrm{b}}$ & $63.99^{\mathrm{b}}$ \\
\hline Significance level & ns & $* *$ & $* *$ & $* *$ \\
\hline $\operatorname{SEM}( \pm)$ & 2.66 & 0.65 & 0.86 & 0.81 \\
\hline \multicolumn{5}{|l|}{ Rate (a.i. $\mathrm{kg} \mathrm{ha}^{-1}$ ) } \\
\hline 0 & $321.88^{\mathrm{a}}$ & $39.37 \mathrm{~d}$ & $56.21^{\mathrm{d}}$ & $48.75^{\mathrm{c}}$ \\
\hline 1 & $255.33^{\mathrm{b}}$ & $49.12 \mathrm{c}$ & $70.36^{\mathrm{c}}$ & $66.81^{\mathrm{b}}$ \\
\hline 2 & $246.76^{\mathrm{bc}}$ & $55.17 \mathrm{~b}$ & $77.50^{\mathrm{b}}$ & $71.01^{\mathrm{a}}$ \\
\hline 3 & $240.73^{c}$ & $59.54 \mathrm{a}$ & $80.71^{\mathrm{ab}}$ & $71.94^{\mathrm{a}}$ \\
\hline 4 & $236.67^{c}$ & $60.39 \mathrm{a}$ & $82.95^{\mathrm{a}}$ & $74.55^{\mathrm{a}}$ \\
\hline Significance level & $* *$ & $* *$ & $* *$ & $* *$ \\
\hline $\operatorname{SEM}( \pm)$ & 4.20 & 1.03 & 1.36 & 1.28 \\
\hline $\mathrm{CV}(\%)$ & 3.95 & 4.77 & 4.53 & 4.71 \\
\hline
\end{tabular}

$\mathrm{ns}, * *$ : non-significant at $5 \%$, significant at $1 \%$ probability level, respectively. Means of the same main effect within a column followed by the same letter are not significantly different at the prescribed level of significance.

\section{Conclusions}

It was observed that time and rate of application of Paclobutrazol did not significantly improve fruit yield of tomato measured in terms of fruit size, pericarp thickness and mean fruit weight. On the contrary, time and rate of application of PBZ compared to the control, significantly increased harvest 
index, yield concentration and index of economic earliness and highly significant variations of both (decreasing and increasing variations) were observed in total fruit yields, marketable fruit yield, fruit yield per plant \& fruit dry weight per plant in comparison with the control. This confirms the results reported in the previous experiments with tomato plants by Bevora and Zlatev [3].

On the basis of this field experiment results, it could be possible to propose that; improvement of seedling quality at planting for increased seedling survival rate and better stress protection; early flower initiation as well as assimilate reallocation to the fruits are significant advantage of PBZ treatments which resulted in early and more fruit production by accelerating generative or reproductive development and hastening early production. Generally, highly significant variations of both (decreasing and increasing) in yield per plant and thereby yield per unit area was observed. Consequently, it is not possible to conclude and recommend based on the result of one time experiment, as a result of this, it could be possible to propose that further investigation should be done in different seasons and at different locations to determine the exact time of application and appropriate rate of PBZ that can increase fruit yield by optimally increasing root growth without excessive reduction in shoot growth.

\section{Acknowledgements}

It is with great pleasure that I acknowledge all those who assisted me and contributed constructive suggestions during the entire study period.

First and foremost I wish to express my deepest appreciation and heartfelt gratitude to my advisors, Dr Tekalign Tsegaw and Dr. Bekele Abebie for their guidance, and support in the execution of the project and preparation of the manuscript.

I would also like to extend my best appreciation to Prof. S. Lal and for his guidance, endless cooperation, enthusiastic effort and direct support in the preparation of the research proposal. Profuse thanks go to Debre Markos Soil Testing Laboratory for providing me technical support and laboratory facilities. I am also highly indebted to Amhara Agricultural and Rural Development Bureau for its financial support.

\section{References}

[1] Asia vegetable research and development center (AVRDC). Proc. of the first international symposium on tropical tomato, Oct. 23-27, 1978 at Shanhua, Taiwan, Republic of China, 1979, pp. 5-10.

[2] J.G. Atherton, J. Rudich, The Tomato Crop, Chapman Hall Ltd. London, New York, 1986, p. 647.

[3] H. Bevora, Z. Zlatev, Physiological response and yield of paclobutrazol treated tomato plants (Lycopersicon esculentum Mill.), Plant Growth Regul. 30 (2000) 117-123.

[4] Frost and Kretchman, Use of growth retardant to improve ripening uniformity and yield of processing tomatoes, HortScience. 22 (1987) 422-423.

[5] P. Hedden, Inhibition of geberellin biosynthesis by paclobutrazol in cell free homogenates of Curcurbita maxima endosperm and malus pumila embryos, J. Plant Growth Regul. 4 (1985) 111-122.

[6] L.C. Ho, Partitioning of assimilates in fruiting tomato plant, Plant Growth Regul. 2 (1984) 277285.

[7] D. Lemma, Seed production guideline for tomatoes, onion and hot pepper, IAR. Addis Ababa., 1998, p. 22.

[8] D. Lemma, Z. Yayeh, E. Herath, Agronomic Studies in Tomato and Capsicum. In; Herath and Lemma (eds). Horticulture Research and Development in Ethiopia. 1-3 December. Addis Ababa, Ethiopia, 1992, pp. 153-163. 
[9] D. Merlo, A. Soldati, E.R. Keller, Influence of growth regulators in abscision of flower and young pods of soybean, Erosoya. 5 (1987) 31-38.

[10] M.D. Orzolek, Use of growth retardant for tomato transplant production, Appl. Agr. Res. 1 (1986) 168-171.

[11] H. E. Park, J. M. Lee, The effect of growth regulator treatments on growth and other characterstics of pepper (Capsicum spp.), Korean Soc. Hort. Sci. 7 (1989) 40-41.

[12] A.M. Pelacho et al., In vitro tuberization of potato: Effect of several morphogenic regulators in light and darkness, J. Plant Physiol. 144 (1994) 705-709.

[13] R.C. Setia, G. Bhatal, N. Setia., Influence of paclobutrazol on growth and yield of Brasica carinata A, Plant Growth Regul. 16 (1999) 121-127.

[14] I. Simko, Effects of paclobutrazol on in vitro formation of potato micro-tubers and their sprouting after storage, Biol. Plant 36 (1994) 15-20.

[15] V. Souza-Machado et al., Enhancement of tomato seedling quality involving triazole seed priming seedling nutrient loading and subsequent effect on harvest yield and quality. Report Ontario. Tomato Seedling Growers Marketing Board in Canada, 1996.

[16] T. Tekalign, P.S. Hammes, Reponse of potato growth under noninductive condition to paclobutrazol. Shoot growth, chlorophyll content, net photosynthesis, assimilate partitioning, tuber yield, quality and dormancy, Plant Growth Regul. 43 (2005) 227-236.

[17] T.D. Davis, E.A. Curry, G.L. Steffens, Chemical regulation of vegetative growth, Critical Reviews in Plant Sciences. 10(2) (1991) 151-188.

[18] L.H. Zhu et al., Changes ofleaf water potential and endogenous cytokinins in young apple treestreated with or without paclobutrazol under drought conditions, Sciences Horticulturae Amsterdam. 99(2) (2004) 133-141.

[19] L.C. Ho, Metabolism and compartmentation of imported sugars in sink organs in relation to sink strength, Annual Review of Plant Physiology and Plant Molecular Biology. 39 (1988) 355378.

[20] L.C. Ho, R.I. Grange, A.F. Shaw, Sourcesink regulation, in: D.A. Baker, J.A. Milburn (Eds.), Transport of Photoassimilates, New York: Longman, 1989, pp. 306-343. 